\title{
Multi-protective role of Echinacea purpurea L. water extract in Allium cepa L. against mercury(II) chloride
}

\author{
Emine Yalçın ${ }^{1} \cdot$ Oksal Macar $^{2} \cdot$ Tuğçe Kalefetoğlu Macar $^{2} \cdot$ Dilek Çavuşoğlu $^{3} \cdot$ Kültiğin Çavuşoğlu ${ }^{1}$
}

Received: 16 February 2021 / Accepted: 20 June 2021 / Published online: 3 July 2021

(C) The Author(s), under exclusive licence to Springer-Verlag GmbH Germany, part of Springer Nature 2021

\begin{abstract}
Mercury $(\mathrm{Hg})$ is a persistent and dangerous heavy metal with genotoxic properties. Echinacea purpurea $\mathrm{L}$. is a well-known therapeutic plant with anti-inflammatory, antioxidant, and anti-tumor properties. In this study, multi-protective role of Echinacea purpurea $\mathrm{L}$. extract against toxicity caused by mercury(II) chloride $\left(\mathrm{HgCl}_{2}\right)$ on Allium cepa $\mathrm{L}$. investigated in a multifaceted way. As a consequence of $100 \mathrm{mgL}^{-1} \mathrm{HgCl}_{2}$ administration, root elongation, weight increase, germination rate, and mitotic index were reduced, whereas micronucleus frequency, chromosomal abnormalities frequency, meristematic cell injuries severity, malondialdehyde level, catalase, and superoxide dismutase activity were increased. On the other hand, co-administration of increasing doses of E. purpurea extract $\left(265 \mathrm{mgL}^{-1}\right.$ and $\left.530 \mathrm{mgL}^{-1}\right)$ and $\mathrm{HgCI}_{2}$ gradually alleviated all observed toxic effects of $\mathrm{HgCI}_{2}$. Protective role of E. purpurea extract against $\mathrm{HgCI}_{2}$-toxicity on A. cepa were clearly demonstrated in this study. The results of this study will lead to future researches investigating use of $E$. purpurea extract against genotoxic contaminants.
\end{abstract}

Keywords Allium cepa L. · Antioxidant $\cdot$ Echinacea purpurea L. $\cdot$ Genotoxicity $\cdot$ Heavy metal $\cdot \mathrm{HgCl}_{2}$

\section{Introduction}

Heavy metal exposure and contamination can cause serious adverse effects on humans, biota, and environment (Bernhoft 2012). Mercury (Hg) is a widely distributed toxic heavy metal in which people are increasingly exposed to (Clarkson and Magos 2006). Eating fish contaminated with $\mathrm{MeHg}$, inhaling $\mathrm{HgO}$ gas, using dental amalgams containing $\mathrm{Hg}$, and vaccines containing thimerosal (an ethylmercury compound) are the most common ways to be exposed to $\mathrm{Hg}$. Exposure to high doses of $\mathrm{Hg}$ causes many adverse health effects in humans, including neurotoxicity, nephrotoxicity, teratogenicity, and immunotoxicity (Branco et al. 2017). It can cause

Responsible Editor: Gangrong Shi

Oksal Macar

oksal.macar@giresun.edu.tr

1 Department of Biology, Faculty of Science and Art, Giresun University, Giresun, Turkey

2 Department of Food Technology, Sebinkarahisar School of Applied Sciences, Giresun University, Giresun, Turkey

3 Department of Plant and Animal Production, Atabey Vocational High School, Isparta University of Applied Sciences, Isparta, Turkey carcinogenic effects by changing the genetic structure in humans (Crespo-López et al. 2009). It is known that the ability to bind with sulfhydryl groups and selenium is especially important part of Hg toxicity (Spiller 2018). Although it is a well-known toxic substance, all the molecular mechanisms underlying the damage caused by $\mathrm{Hg}$ are still unclear (Andreoli and Sprovieri 2017).

Plants have been used as an important tool for disease prevention in traditional ethnomedical practices for a long time (Nadaf et al. 2019). Today, herbal products account for about $30 \%$ of the pharmaceutical market and $11 \%$ of essential drugs (Sousa et al. 2018). Echinacea purpurea L. (Asteraceae), a perennial herb native to Eastern North America, has been used to prevent or treat colds, cough, bronchitis, and mouth and pharynx inflammation (Hohmann et al. 2011). It also has positive effects in healing wounds, relieving migraine and anxiety, and strengthening immunity (Sharif et al. 2021). Therefore, the demand for pills, ointments, and teas containing E. purpurea has increased. Products and extracts prepared from Echinacea spp. are one of the most widely used herbal health products in both North America and Europe (Barrett 2003). The anti-inflammatory, antioxidant, and anti-tumor properties of $E$. purpurea are also well known (Cheng et al. 2020). Echinacea preparations are also considered to be effective in the treatment of SARS-CoV-2 with their 
virucidal properties (Signer et al. 2020). Major phytochemicals responsible for the biological properties of $E$. purpurea properties are alkamides, betaine, lipoproteins, polysaccharides, polyacetylene, saponins, sesquiterpenes, and phenolic compounds (echinacoside and other caffeic acid derivatives and chicoric acid) (Coelho et al. 2020). Sharif et al. (2021) mentioned that $E$. purpurea may be used in treatment of human cervix adenocarcinoma due to its high antiproliferative activity and chicoric acid content. In addition, Echinacea preparations can be used safely at recommended doses, as it is safe and non-toxic (Xu et al. 2021).

As a higher model plant, Allium cepa $\mathrm{L}$. has been used since the 1940s to evaluate DNA damage caused by various mutagens. The A. cepa test correlates well with other test systems as well as being an inexpensive, easy, and fast test to identify mutagens (Leme and Marin-Morales 2009). The A. cepa test has been successfully used by researchers to determine the genotoxic effects of heavy metals (Seth et al. 2008; Y1ldız et al. 2009; Barbosa et al. 2010; Gupta et al. 2018) and the protective effects of plant extract against heavy metal-induced genotoxicity (Glińska et al. 2007; Basu et al. 2019; Macar et al. 2020; Kalefetoğlu Macar et al. 2021).

The objective of the work is to determine the toxicity caused by mercury(II) chloride on A. cepa and whether E. purpurea extract (EPE) had a multi-protective effect against it. For this purpose, root elongation, weight increase, and germination rate were investigated as growth parameters, while mitotic index (MI), micronucleus (MN), and chromosomal abnormalities (CAs) were evaluated as genotoxicity parameters. In addition, biochemical parameters [malondialdehyde (MDA) level, catalase (CAT), and superoxide dismutase MDA activity] and meristematic cell injuries in A. cepa roots were also investigated.

\section{Materials and methods}

\section{Materials}

A. cepa bulbs were purchased from local market. Mercury(II) chloride $\left(\mathrm{HgCl}_{2}\right)$ (Merck, CAS Number 7487-94-7) was used to prepare Hg solutions. E. purpurea extract (EPE) with $4 \%$ phenol content (Sepe Natural Izmir / Turkey) is obtained commercially.

\section{Experimental design}

Bulbs with similar weight were sterilized using $2.5 \% \mathrm{NaClO}$ after their outermost scales were peeled off. Six treatment group were formed using sterilized bulbs: treatment I (control: tap water), treatment II (265 $\left.\mathrm{mgL}^{-1} \mathrm{EPE}\right)$, treatment III (530 $\mathrm{mgL}^{-1}$ EPE), treatment IV $\left(100 \mathrm{mgL}^{-1} \mathrm{HgCl}_{2}\right)$, treatment $\mathrm{V}$ $\left(265 \mathrm{mgL}^{-1} \mathrm{EPE}+100 \mathrm{mgL}^{-1} \mathrm{HgCI}_{2}\right)$, and treatment VI (530
$\mathrm{mgL}^{-1} \mathrm{EPE}+100 \mathrm{mgL}^{-1} \mathrm{HgCl}_{2}$ ). Concentrations of aqueous solutions of EPE were chosen based on the daily dose (530 $\mathrm{mg}$ ) recommended by manufacturer and half of this dose (265 $\mathrm{mg}$ ). Experimental dose of $\mathrm{HgCI}_{2}$ was obtained from Çavuşoğlu et al. (2018).

\section{Determination of growth parameters}

Bulbs in each group were germinated in the mentioned solutions for $72 \mathrm{~h}$ at room temperature $\left(23^{\circ} \mathrm{C}\right)$ in the dark. At the end of the germination period, germination rates were determined over 50 onions as percentages. On the other hands, mean root lengths and mean weight gains of each group determined over 10 bulbs.

\section{Determination of genotoxicity parameters}

Tips of the freshly germinated roots of $A$. cepa were used to determine genotoxicity. At the end of 3-day experimental period, $1-1.5 \mathrm{~mm}$ parts of the root tips of $A$. cepa were cut with a razor blade. Root tips were pretreated using paradichlorobenzene (saturated) for $4 \mathrm{~h}$ before they were fixed with a mixture of ethanol and acetic acid (3: 1) at $23{ }^{\circ} \mathrm{C}$ for 1 day. Root tips were hydrolyzed in $\mathrm{HCl}(1 \mathrm{~N})$ for 16 min at 60 ${ }^{\circ} \mathrm{C}$. Hydrolyzed root tips were stained with Feulgen solution for $2 \mathrm{~h}$, and then they were crushed between lamella and coverslip using one drop of acetic acid (\%45) to obtain squash slides (Sharma and Gupta 1982). The level of MI, MN frequency, and CAs frequency were screened using a research microscope (Olympus CX41 with Olympus C-5060 camera) at $500 \times$ magnification. MI is considered to be the ratio between the number of dividing cells and the total number of cells observed. To calculate MI; ten slides from each group analyzed from each group and 1,000 cells were observed from each slide (total 10,000 cells for each group) and expressed as a percentage. MI formation was determined according to the rules proposed by Fenech et al. (2003). According to these rules, (a) the diameter of the $\mathrm{MN}$ is $1 / 3$ of the cell nucleus or smaller, (b) the shape of the MN is round or oval, and (c) MN does not contacted to the nucleus. To calculate frequencies of CAs and $\mathrm{MN}$, ten slides were analyzed from each group analyzed from each group and 100 cells were observed from each slide (total 1,000 cells for each group).

\section{Determination of MDA level}

MDA levels in A. cepa roots were analyzed to assess the level of lipid peroxidation in tissues. The method proposed by Unyayar et al. (2006) was carried out with some minor modifications to determine MDA levels. One gram of root sample was homogenized using trichloroacetic acid $(2 \mathrm{~mL}$ of $5 \%$; TCA) solution. Homogenized tissues were centrifuged at 23 ${ }^{\circ} \mathrm{C}$ for $15 \mathrm{~min}$ at $12,000 \mathrm{rpm}$. One milliliter of TCA (20\%), 
$1 \mathrm{~mL}$ of thiobarbituric acid (TBA) $(0.5 \%)$, and $1 \mathrm{~mL}$ of supernatant were collected in a tube and then boiled in hot bath for $30 \mathrm{~min}$. After incubation, reaction mixture was transferred to an ice bath to stop reaction. The mixture was centrifuged at $10,000 \mathrm{rpm}$ for $5 \mathrm{~min}$ before its supernatant was observed spectrophotometrically at $532 \mathrm{~nm}$.

\section{Determination of CAT and SOD enzyme activities}

The same extraction method was used for CAT and SOD activity analysis. Root tissue ( $1 \mathrm{~g}$ ) was homogenized using $10 \mathrm{~mL} \mathrm{pH} \mathrm{7.8-sodium} \mathrm{phosphate} \mathrm{buffer} \mathrm{and} \mathrm{then} \mathrm{centrifuged}$ at $10,500 \mathrm{rpm}$ for $20 \mathrm{~min}$ at $4{ }^{\circ} \mathrm{C}$. Supernatants of homogenates were used in SOD and CAT activity analysis.

To determine CAT enzyme activity, a mixture containing 3 $\mathrm{mL}$ of $\mathrm{pH} 7.8$-sodium phosphate buffer $(200 \mathrm{mM}), 0.6 \mathrm{~mL}$ of $\mathrm{H}_{2} \mathrm{O}_{2}(0.1 \mathrm{M})$, and $2.0 \mathrm{~mL}$ of distilled water was prepared (Beers and Sizer 1952). The reaction was started by adding $0.4 \mathrm{~mL}$ extract. In reaction mixture, the absorbance was reduced as a result of $\mathrm{H}_{2} \mathrm{O}_{2}$ consumption. CAT enzyme activity was expressed as $\mathrm{OD}_{240} \mathrm{~nm}$ min $\mathrm{g}^{-1} \mathrm{FW}$.

SOD enzyme activity was evaluated using a mixture containing $3 \mathrm{~mL}$ pH 7.8-sodium phosphate buffer $(0.05 \mathrm{M}), 0.56$ $\mathrm{mL}$ deionized water, $0.6 \mathrm{~mL}$ nitroblue tetrazolium chloride, $0.6 \mathrm{~mL}$ methionine, $0.6 \mathrm{~mL}$ EDTA- $\mathrm{Na}_{2}, 0.6 \mathrm{~mL}$ riboflavin, $0.02 \mathrm{~mL}$ insoluble polyvinylpyrrolidone $(4 \%)$, and $0.02 \mathrm{~mL}$ extract (Beauchamp and Fridovich 1971). A powerful lamp (A $215 \mathrm{~W}$ ) was used to initiate the reaction. The absorbance of the reaction mixture was observed for $10 \mathrm{~min}$ at $560 \mathrm{~nm}$ using a spectrophotometer. SOD enzyme activity was expressed as $\mathrm{Umg}^{-1}$ FW. MDA, SOD, and CAT assays were performed in triplicate.

\section{Determination of meristematic cell injuries}

Possible cell injuries were investigated in root tip meristematic tissue of $A$. серa. Cross-sections were taken manually from the newly emerged roots with a razor blade. A drop of methylene blue $(1 \%)$ was used to stain cross-section slides. Slides were scanned with a research microscope (Olympus CX41 and Olympus C-5060 camera) for possible meristematic cell injuries under 500× magnification (Tütüncü et al. 2019). Meristematic cell injuries were scored according to their intensity (none, slight, moderate, and severe).

\section{Statistical analysis}

The data was analyzed with the use of analysis of variance (ANOVA) test and Duncan's test with $p$ value $<0.05$. Analyses were performed using SPSS version 23 software (SPSS Inc., Chicago, IL, USA). Results were expressed as mean \pm SD (standard deviation).

\section{Results and discussion}

The effects of $\mathrm{HgCI}_{2}$ and EPE on growth parameters of A. cepa on germination period are shown in Table 1 . As a result of the application of $265 \mathrm{mgL}^{-1} \mathrm{EPE}$ and $530 \mathrm{mgL}^{-1}$ EPE on A. серa, no statistical difference was observed in terms of root elongation, weight gain, and germination rate. EPE did not inhibit the growth of $A$. cepa as germination occurred. Uninhibited growth parameters with increasing doses of EPE indicated that EPE did not cause toxic effects on $A$. cepa during germination. On the other hand, administration of $100 \mathrm{mgL}^{-1} \mathrm{HgCI}_{2}$ induced significant inhibition in root elongation $(78 \%)$, weight gain $(94 \%)$, and germination rate $(57 \%)$ compared to control. $\mathrm{Hg}$ is a well-known toxic pollutant for organisms (Spiller 2018). Hg negatively affects permeability of cell membranes, activity of mitochondrial, and substitution of essential cations in plants (Nagajyoti et al. 2010). The toxic effects of $\mathrm{Hg}$ are more intense in the embryo with high sulfhydryl group content (Patra and Sharma 2000). Our results indicating inhibitory role $\mathrm{HgCI}_{2}$ in root elongation, weight gain, and germination rate on $A$. серa were consistent with previous study of Çavuşoğlu et al. (2018) and Sharma et al. (2012). Remarkably, co-administration of EPE (265 $\mathrm{mgL}^{-1}$ and $530 \mathrm{mgL}^{-1}$ ) with $100 \mathrm{mgL}^{-1} \mathrm{HgCl}_{2}$ significantly reduced the inhibitory effects of $\mathrm{Hg}$ on growth parameters in a dose-dependent manner $(\mathrm{p}<0.05)$. Both EPE applications along with $100 \mathrm{mgL}^{-1}$ were insufficient to fully prevent the inhibition on growth parameters resulting from hg toxicity. Application of $530 \mathrm{mgL}^{-1} \mathrm{EPE}+100 \mathrm{mgL}^{-1}$ $\mathrm{HgCl}_{2}$ showed the best restoration rate on growth parameters; root elongation, weight gain, and germination rate increased to $65 \%, 57 \%$, and $78 \%$ of their control levels, respectively. The presence of EPE reduced the toxicity caused by $\mathrm{HgCl}_{2}$ when considering growth parameters during germination. This study is the first to show the protective effect of EPE against $\mathrm{HgCI}_{2}$ poisoning in a plant. Considering that oxidative stress is a crucial part of the toxicity caused by $\mathrm{Hg}$ (Hansen et al. 2001), it can be concluded that high antioxidant capacity of EPE plays an important role in reducing the damage caused by this oxidative stress.

$\mathrm{MI}$, an indicator of cell proliferation, is a parameter to evaluate the cytotoxicity of materials (Leme and MarinMorales 2009). Micronucleus test can be used to determine the genotoxicity of materials based on micronucleus formation (Bolognesi et al. 2013). Effects of $\mathrm{HgCI}_{2}$ and EPE on genotoxicity parameters are presented in Table 2 and Fig. 1. In accordance with growth parameters, MI level, MN, and CAs frequencies were not affected as a result of increasing doses of EPE $\left(265 \mathrm{mgL}^{-1}\right.$ and 530 $\left.\mathrm{mgL}^{-1}\right)(\mathrm{p}<0.05)$. According to the investigated genotoxicity parameters, EPE application did not induce any genotoxic effect on $A$. cepa bulbs. On the other hand, in the treatment of $100 \mathrm{mgL}^{-1} \mathrm{HgCl}_{2}$, MI level decreased 
Table 1 Effects of $\mathrm{HgCl}_{2}$ and EPE on growth parameters on germination period

\begin{tabular}{llll}
\hline Treatments & Root elongation $(\mathrm{cm})$ & Weight increase $(\mathrm{g})$ & Germination rate $(\%)$ \\
\hline Control & $9.00 \pm 1.48^{\mathrm{a}}$ & $5.75 \pm 0.83^{\mathrm{a}}$ & 99 \\
$265 \mathrm{mgL}^{-1} \mathrm{EPE}$ & $9.16 \pm 1.50^{\mathrm{a}}$ & $5.82 \pm 0.82^{\mathrm{a}}$ & 98 \\
$530 \mathrm{mgL}^{-1} \mathrm{EPE}$ & $9.24 \pm 1.52^{\mathrm{a}}$ & $5.80 \pm 0.82^{\mathrm{a}}$ & 100 \\
$100 \mathrm{mgL}^{-1} \mathrm{HgCl}_{2}$ & $2.00 \pm 0.88^{\mathrm{d}}$ & $0.35 \pm 0.02^{\mathrm{d}}$ & 42 \\
$265 \mathrm{mgL}^{-1} \mathrm{EPE}+100 \mathrm{mgL}^{-1} \mathrm{HgCl}_{2}$ & $3.75 \pm 1.16^{\mathrm{c}}$ & $1.50 \pm 0.15^{\mathrm{c}}$ & 57 \\
$530 \mathrm{mLL}^{-1} \mathrm{EPE}+100 \mathrm{~mL}^{-1} \mathrm{HgCI}_{2}$ & $5.90 \pm 1.62^{\mathrm{b}}$ & $3.27 \pm 0.23^{\mathrm{b}}$ & 77 \\
\hline
\end{tabular}

Means with the different letter within the same column are statistically different
$(45 \%)$ and the frequency of $\mathrm{MN}(48.10 \pm 4.74)$ and $\mathrm{CA}$ increased compared to the control $(\mathrm{p}<0.05)$. The decrease in MI, an indicator of cell proliferation, was consistent with the growth parameters of this study. Decreased MI rate in the results indicated slower mitotic cell division in the meristem. Since both occur by mitotic division, root elongation and weight gain decreased as the MI value decreased. Following MN (Fig. 1a), the most common CAs in $100 \mathrm{mgL}^{-1} \mathrm{HgCl}_{2}$ application were fragment chromosomes (Fig. 1b), sticky chromosomes (Fig. 1c), and vagrant chromosomes (Fig. 1d), respectively. According to the results of the genotoxicity parameters, $\mathrm{HgCl}_{2}$ induced notable genotoxic effects on A. cepa. In line with our results, Çavuşoğlu et al. (2018) also reported that MN, fragment formation, and sticky chromosomes were the most common CAs in A. cepa as a result of $\mathrm{HgCl}_{2}$ application. The ability of $\mathrm{Hg}$ to bind to functional groups containing sulfhydryl, selenium, sulfur, nitrogen, and thiol leads to indirect accumulation of reactive oxygen species (ROS) through inactivation of enzymes (Ynalvez et al.
2016; Spiller 2018). Oxidative stress caused by ROS is one of the most important causes of Hg's genotoxicity, as well as disruptive effects of $\mathrm{Hg}$ on microtubules, DNA, and DNA repair mechanism (Crespo-López et al. 2009).

Co-administration of EPE with $\mathrm{HgCl}_{2}$ significantly prevented genotoxic damage, even though none of the genotoxicity parameters returned the original control levels. The best anti-genotoxic effect of EPE was observed at 530 $\mathrm{mgL}^{-1} \mathrm{EPE}+100 \mathrm{mgL}^{-1} \mathrm{HgCl}_{2}$ administration, in which MI increased to $75 \%$ of control and total CAs (including $\mathrm{MN}$ ) decreased to $45 \%$ of $100 \mathrm{mgL}^{-1} \mathrm{HgCl}_{2}$ administration. In addition to $\mathrm{MN}$, the frequencies of other $\mathrm{CAs}$ also decreased with increasing EPE doses. Our results indicating antigenotoxic effects of EPE are consistent with Tsai et al. (2012) that mentioned antimutagenic properties of EPE with high caffeic acid content on Salmonella typhimurium TA98 and TA100. Similarly, Joksić et al. (2009) reported that EPE had powerful protective properties against radiation on radiation workers. The anti-genotoxic and genoprotective abilities of EPE are related to its antioxidant components such as phe-

Table 2 Effects of $\mathrm{HgCI}_{2}$ and EPE on genotoxicity parameters

\begin{tabular}{|c|c|c|c|c|c|c|}
\hline Chromosomal Aberrations & Control & $\begin{array}{l}265 \mathrm{mgL}^{-1} \\
\mathrm{EPE}\end{array}$ & $\begin{array}{l}530 \mathrm{mgL}^{-1} \\
\mathrm{EPE}\end{array}$ & $\begin{array}{l}100 \mathrm{mgL}^{-1} \\
\mathrm{HgCI}_{2}\end{array}$ & $\begin{array}{l}265 \mathrm{mgL}^{-1} \mathrm{EPE}+100 \mathrm{mgL}^{-1} \\
\mathrm{HgCI}_{2}\end{array}$ & $\begin{array}{l}530 \mathrm{mgL}^{-1} \mathrm{EPE}+100 \mathrm{mgL}^{-1} \\
\mathrm{HgCI}_{2}\end{array}$ \\
\hline MI $(\%)$ & $8.17 \pm 0.28^{\mathrm{a}}$ & $8.24 \pm 28 .^{\mathrm{a}}$ & $8.31 \pm 0.29^{\mathrm{a}}$ & $4.50 \pm 0.18^{\mathrm{d}}$ & $5.12 \pm 0.20^{\mathrm{c}}$ & $6.16 \pm 0.22^{\mathrm{b}}$ \\
\hline $\mathrm{MN}$ & $0.18 \pm 0.24^{\mathrm{d}}$ & $0.00 \pm 0.00^{\mathrm{d}}$ & $0.00 \pm 0.00^{\mathrm{d}}$ & $48.10 \pm 4.74^{\mathrm{a}}$ & $41.30 \pm 3.85^{\mathrm{b}}$ & $35.70 \pm 3.18^{\mathrm{c}}$ \\
\hline FRG & $0.00 \pm 0.00^{\mathrm{d}}$ & $0.00 \pm 0.00^{\mathrm{d}}$ & $0.00 \pm 0.00^{\mathrm{d}}$ & $35.60 \pm 3.88^{\mathrm{a}}$ & $27.10 \pm 3.24^{\mathrm{b}}$ & $20.50 \pm 2.93^{\mathrm{c}}$ \\
\hline $\mathrm{SC}$ & $0.16 \pm 0.22^{\mathrm{d}}$ & $0.12 \pm 0.18^{\mathrm{d}}$ & $0.00 \pm 0.00^{\mathrm{d}}$ & $30.20 \pm 3.11^{\mathrm{a}}$ & $24.50 \pm 2.78^{b}$ & $16.60 \pm 2.10^{\mathrm{c}}$ \\
\hline $\mathrm{VC}$ & $0.00 \pm 0.00^{\mathrm{d}}$ & $0.00 \pm 0.00^{\mathrm{d}}$ & $0.00 \pm 0.00^{\mathrm{d}}$ & $24.10 \pm 2.98^{\mathrm{a}}$ & $18.90 \pm 2.54^{\mathrm{b}}$ & $12.30 \pm 1.96^{\mathrm{c}}$ \\
\hline $\mathrm{B}$ & $0.00 \pm 0.00^{\mathrm{d}}$ & $0.00 \pm 0.00^{\mathrm{d}}$ & $0.00 \pm 0.00^{\mathrm{d}}$ & $20.40 \pm 2.12^{\mathrm{a}}$ & $14.80 \pm 1.91^{\mathrm{b}}$ & $9.60 \pm 1.63^{\mathrm{c}}$ \\
\hline UDC & $0.00 \pm 0.00^{\mathrm{d}}$ & $0.00 \pm 0.00^{\mathrm{d}}$ & $0.00 \pm 0.00^{\mathrm{d}}$ & $15.30 \pm 1.77^{\mathrm{a}}$ & $9.70 \pm 1.36^{\mathrm{b}}$ & $5.20 \pm 0.98^{\mathrm{c}}$ \\
\hline IM & $0.00 \pm 0.00^{\mathrm{d}}$ & $0.00 \pm 0.00^{\mathrm{d}}$ & $0.00 \pm 0.00^{\mathrm{d}}$ & $11.30 \pm 1.10^{\mathrm{a}}$ & $7.60 \pm 0.79^{\mathrm{b}}$ & $3.50 \pm 0.55^{\mathrm{c}}$ \\
\hline ND & $0.00 \pm 0.00^{\mathrm{d}}$ & $0.00 \pm 0.00^{\mathrm{d}}$ & $0.00 \pm 0.00^{\mathrm{d}}$ & $6.40 \pm 0.94^{\mathrm{a}}$ & $3.80 \pm 0.57^{\mathrm{b}}$ & $1.90 \pm 0.44^{\mathrm{c}}$ \\
\hline
\end{tabular}

Means with the different letter within the same line are statistically different. $M I$ mitotic index, $M N$ micronucleus, $F R G$ fragment, $S C$ sticky chromosome, $V C$ vagrant chromosome, $B$ bridge, $U D C$ unequal distribution of chromatin, $I M$ irregular mitosis, $N D$ nucleus damage 
Fig. 1 Chromosomal aberrations induced by $\mathrm{HgCI}_{2}$. a $\mathrm{MN}$, b fragment in anaphase, $\mathbf{c}$ sticky chromosome, $\mathbf{d}$ vagrant in anaphase, e-f bridge in in anaphase, $\mathbf{g}$ unequal distribution of chromatin in anaphase, $\mathbf{h}$ irregular mitosis, i nucleus damage
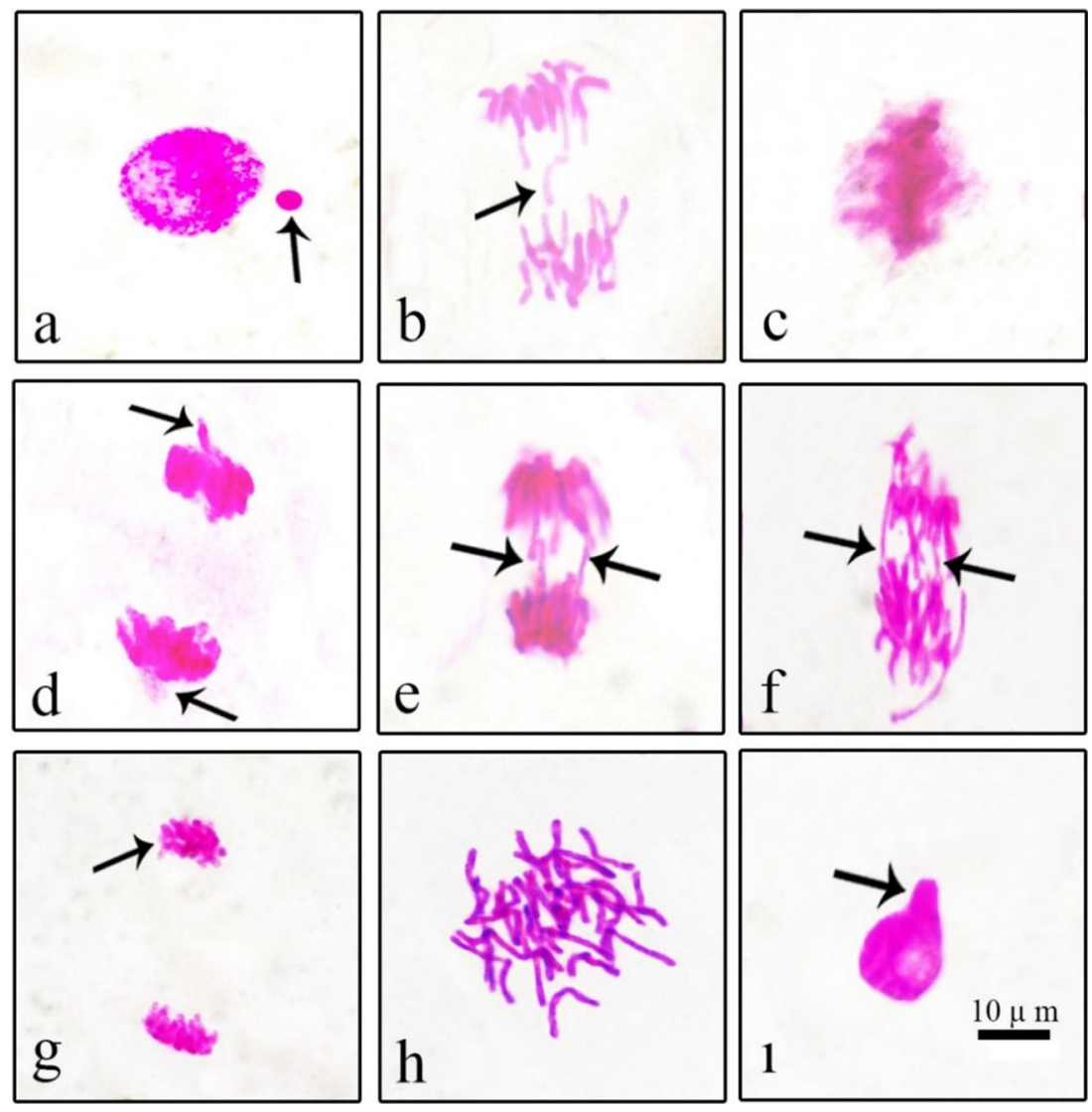

nols, caftaric acid, caffeic acid, chicoric acid, cyclic acid, and echinocyte, which scavenge free radicals and bind metals (Dalby-Brown et al. 2005; Joksić et al. 2009; Tsai et al. 2012; Islam et al. 2021). Caftaric acid, one of the main components of EPE, also has genoprotective, antioxidant, antiinflammatory, antimutagenic, and anticarcinogenic effects (Koriem 2020). Espinosa-Paredes et al. (2020) reported that Echinacea extract containing high dose of echinacoside and caffeic acid arrested breast cancer MDA-MB-231 cells in the G1 phase but did not affect normal breast cells. The antiproliferative effects of EPE against cancer cells (Driggins et al. 2017; Karimi et al. 2019; Espinosa-Paredes et al. 2020; Sharif et al. 2021) indicate that EPE not only protects DNA with its antioxidant capacity, but also helps to eliminate cells with chromosomal abnormalities. In addition, Coelho et al. (2020) pointed out that the synergistic effects of compounds in EPE are stronger than the effects of these compounds alone.

Protective enzymes against oxygen free radicals such as CAT and SOD can be accepted as circumstantial evidence for enhanced production of ROS. Oxidative stress-induced lipid peroxidation damage in the cell can be determined by measuring the MDA level (Huang et al. 1996). The effect of EPE and $\mathrm{HgCI}_{2}$ applications on MDA level, CAT, and SOD activities was shown in Fig. 2. MDA levels and CAT (Fig. 2a) and SOD (Fig. 2b) activities were not significantly affected by the $265 \mathrm{mgL}^{-1}$ and $530 \mathrm{mgL}^{-1} \mathrm{EPE}$ administrations compared to the control. Applications of EPE did not cause oxidative stress in the terms of selected biochemical parameters. In contrast, MDA (Fig. 2c) level (2.7 times), CAT activity (2.9 times), and SOD activity (2.1times) excessively elevated as a result of $100 \mathrm{mgL}^{-1} \mathrm{HgCI}_{2}$ compared to control. Our results of oxidative stress were in correspondence with previous studies on other plants such as duckweed (Zhang et al. 2017), tomato (Cho and Park 2000), wheat (Sahu et al. 2012), and rice (Chen et al. 2012). In addition, Rodríguez-Sánchez et al. (2012) and Teixeira et al. (2018) also mentioned that $\mathrm{HgCI}_{2}$ induced oxidative stress in rats. MDA levels and CAT and SOD enzyme activities were gradually reduced in applications EPE $\left(265 \mathrm{mgL}^{-1}\right.$ and $\left.530 \mathrm{mgL}^{-1}\right)$ together with $\mathrm{HgCl}_{2}$ compared $\mathrm{HgCl}_{2}$ application. Although EPE greatly reduced oxidative stress, MDA levels and CAT and SOD enzyme activities did not reach the control level. The ability of EPE to reduce oxidant stress in vivo was already reported by Hou et al. (2020) and Karg et al. (2019). Mohamed et al. (2020) also mentioned that EPE has a protective effect against aluminum-induced reproductive toxicity in rats due to its strong radical scavenging activity. The main mechanism of toxicity of metals is based on free radical production and inducing oxidative stress. Plant-based antioxidant molecules facilitate the neutralization of ROS and alleviation oxidative stress in living systems (Singh and Sharma 2020). EPE supported antioxidant defense mechanism of plant with its 

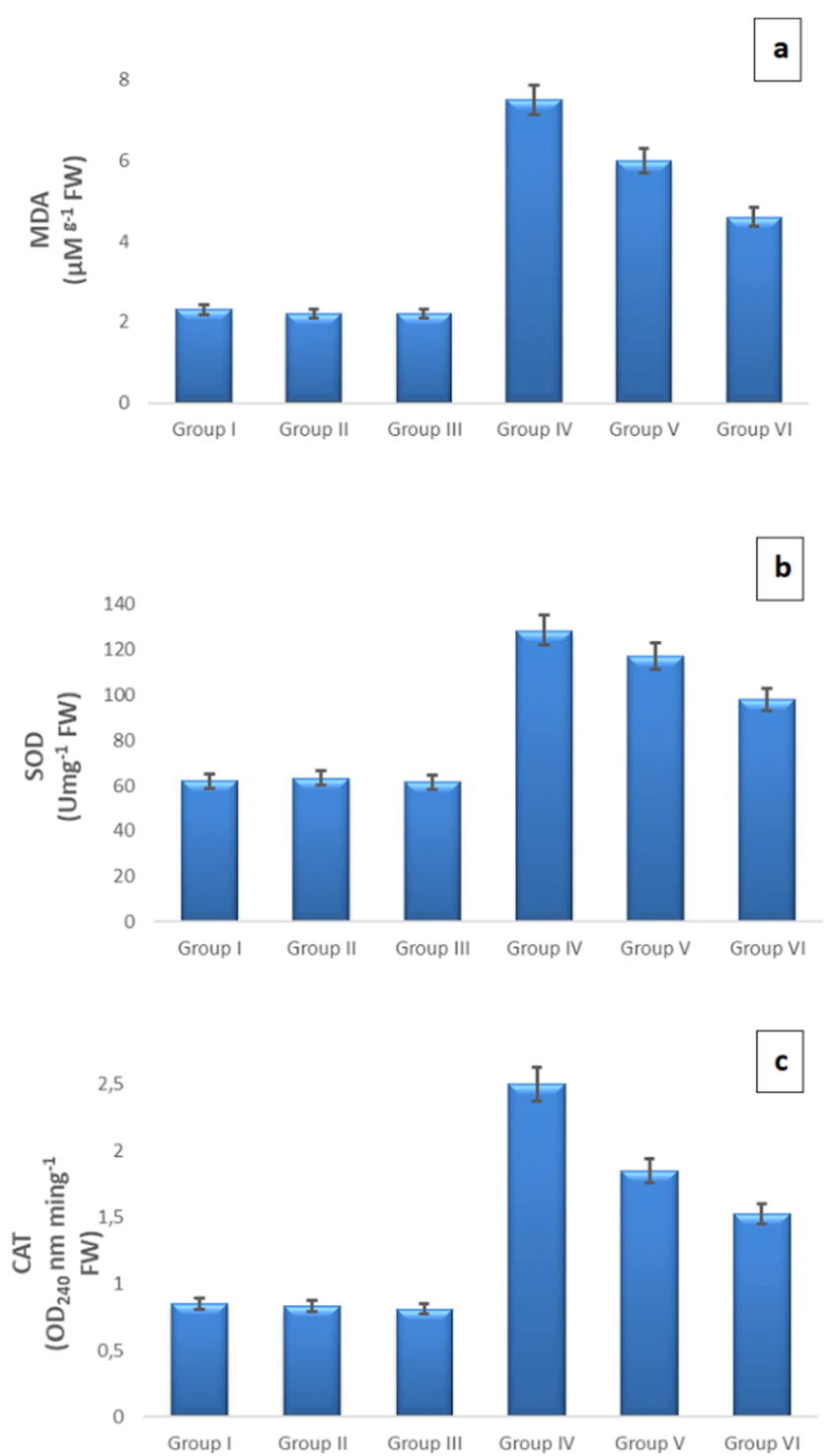

Fig. 2 Effects of EPE and $\mathrm{HgCI}_{2}$ on MDA level (a), CAT (b), and SOD (c) activities. (Group I: Control, Group II: $265 \mathrm{mgL}^{-1} \mathrm{EPE}$, Group III: 530 $\mathrm{mgL}^{-1}$ EPE, Group IV: $100 \mathrm{mgL}^{-1} \mathrm{HgCI}_{2}$, Group V: $265 \mathrm{mgL}^{-1} \mathrm{EPE}+$ $100 \mathrm{mgL}^{-1} \mathrm{HgCl}_{2}$, Group VI: $\left.530 \mathrm{mgL}^{-1} \mathrm{EPE}+100 \mathrm{mgL}^{-1} \mathrm{HgCI}_{2}\right)$. Vertical bars denote standard error $(n=10)$

powerful antioxidant biomolecules such as phenols, caffeic acid, cyclic acid, and echinacosides. Similar to our study, Sharif et al. (2021) noted that high antioxidants capacity of EPE protected DNA against damage. On the other hand, Espinosa-Paredes et al. (2020) mentioned that components of Echinacea possibly have some special molecular interactions and defense promoting effects.

Roots tend to accumulate $\mathrm{Hg}$ more than upper parts of the plants (Cho and Park 2000) as it is the first contact site. Due to higher accumulation of $\mathrm{Hg}$, the most serious damage can be expected to be in the roots. Table 3 shows alleviative effect of EPE against meristematic cell injuries caused by $\mathrm{HgCI}_{2}$. $\mathrm{HgCI}_{2}$-induced meristematic cell injuries were presented in Fig. 2. Applications of $265 \mathrm{mgL}^{-1} \mathrm{EPE}$ and $530 \mathrm{mgL}^{-1} \mathrm{EPE}$
Table 3 Alleviative effect of EPE against meristematic cell injuries caused by $\mathrm{HgCl}_{2}$

\begin{tabular}{lllll}
\hline Treatments & ECD & TCCW & CCD & FCD \\
\hline Control & - & - & - & - \\
$265 \mathrm{mgL}^{-1} \mathrm{EPE}$ & - & - & - & - \\
$530 \mathrm{mgL}^{-1} \mathrm{EPE}$ & - & - & - & - \\
$100 \mathrm{mgL}^{-1} \mathrm{HgCI}$ & ++ & ++ & ++ & +++ \\
$265 \mathrm{mgL}^{-1} \mathrm{EPE}+100 \mathrm{mgL}^{-1} \mathrm{HgCI}_{2}$ & ++ & + & + & ++ \\
$530 \mathrm{mgL}^{-1} \mathrm{EPE}+100 \mathrm{mgL}^{-1} \mathrm{HgCl}_{2}$ & + & + & - & + \\
\hline
\end{tabular}

$E C D$ epidermis cell damage, $T C C W$ thickening of the cortex cell wall, $C C D$ cortex cell damage, $F C N$ flattened cell nucleus. (-): none; (+): slight; $(++)$ : moderate; $(+++)$ : severe.

did not cause any meristematic cell injuries in A. cepa roots. In contrast, severe epidermis cell damage (Fig. 3d), moderate thickening of the cortex cell wall (Fig. 3e), moderate cortex cell damage (Fig. 3e), and severe flattened cell nucleus (Fig. 3f) were observed as a result of $100 \mathrm{mgL}^{-1} \mathrm{HgCl}_{2}$ administration. These results were consistent with growth retardation, genotoxicity, and oxidative stress results of the present study. Our results regarding $\mathrm{Hg}$-induced meristematic cell injuries on A. cepa were in correspondence with findings of Çavuşoğlu et al. (2018); however, indistinct transmission tissue damage did not be clearly observed or photographed in the present study. Considering our MDA level results, oxidative stress which induced damages on cell membranes may be the main cause of structural deformations in meristematic tissue. In addition to membrane injuries caused by lipid peroxidation, flattened cell nucleus may be an indicator of damaged genetic material caused by genotoxicity of $\mathrm{HgCl}_{2}$. Co-administrations of $\mathrm{EPE}$ with $\mathrm{HgCl}_{2}$ reduced intensities of cell injuries in dosedependent manner. The best healing effect of EPE was observed on $530 \mathrm{mgL}^{-1} \mathrm{EPE}+100 \mathrm{mgL}^{-1} \mathrm{HgCl}_{2}$ treatment. EPE application effectively reduced meristematic cell damage induced by $\mathrm{HgCl}_{2}$ owing to its high antioxidant capacity.

\section{Conclusion}

The results of this study showed that $\mathrm{HgCl}_{2}$ treatment had toxic effects on all parameters investigated in A. cepa. On the other hand, application of $265 \mathrm{mgL}^{-1}$ and $530 \mathrm{mgL}^{-1}$ of EPE elevated all adverse effects on all parameters in dose-dependent manner. Data from this study showed that potent antioxidant capacity of EPE combats the Hg-induced genotoxic effects by reducing the oxidative stress. In conclusion, protective properties of EPE against toxicity caused by $\mathrm{HgCI}_{2}$ on $A$. cepa are revealed with versatile study. This study also contributed to the literature on the toxic effects of Hg. In order to use EPE as a protectant against genotoxic contaminants, more detailed researches are needed on its protective mechanism. 


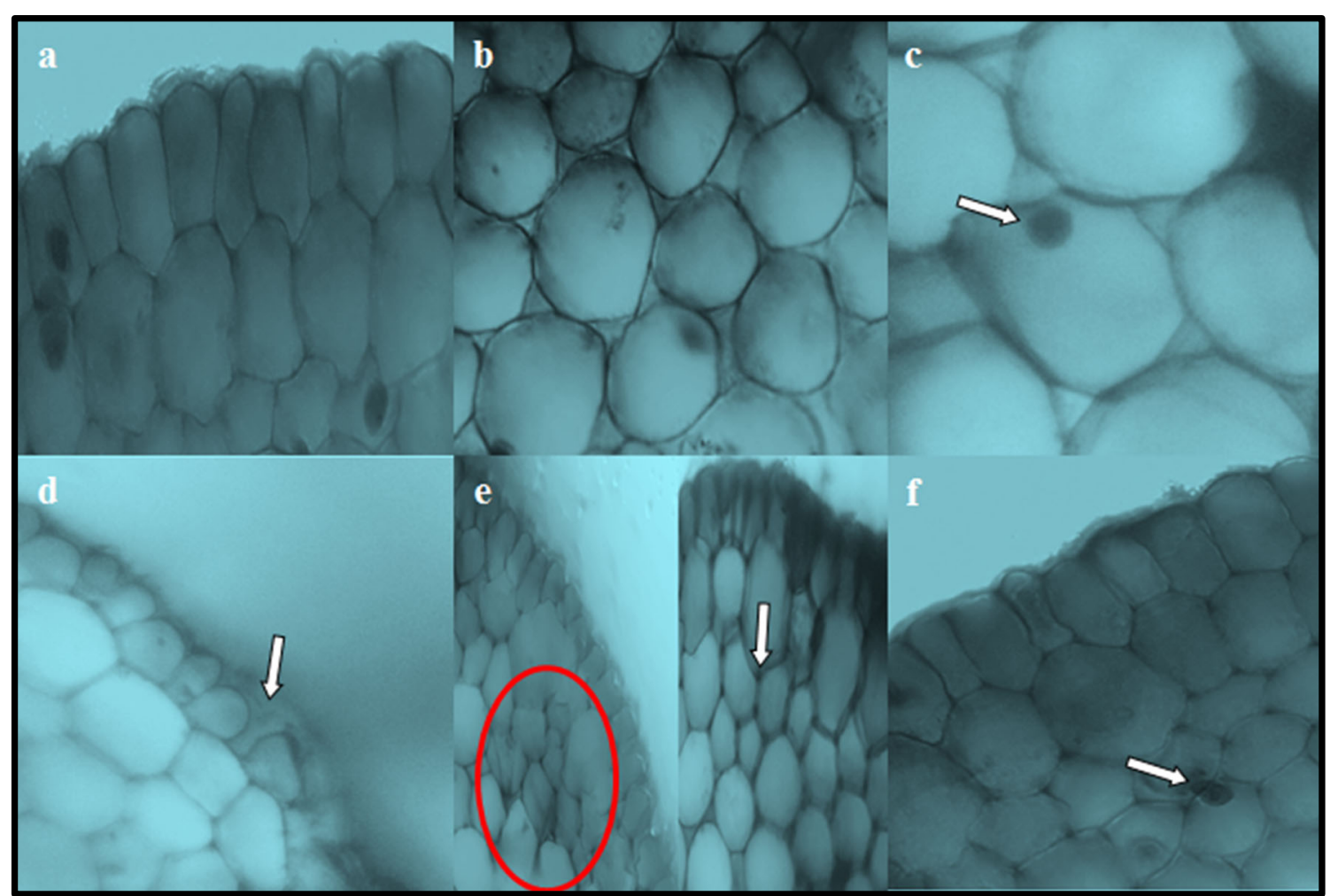

Fig. $3 \mathrm{HgCl}_{2}$-induced meristematic cell injuries. a Normal appearance of epidermis cells, $\mathbf{b}$ normal appearance of cortex cells, $\mathbf{c}$ normal appearance of nucleus (oval), $\mathbf{d}$ epidermis cell damage, $\mathbf{e}$ cortex cell damage (red circle) and thickening of the cortex cell wall, $\mathbf{f}$ flattened cell nucleus

Author contribution Dr. Emine Yalçın, Dr. Oksal Macar, Dr. Tuğçe Kalefetoğlu Macar, Dr. Dilek Çavuşoğlu, and Dr. Kültiğin Çavuşoğlu carried out the experimental stages, manuscript preparation, and statistical analysis.

Data availability All data generated or analyzed during this study are included in this published article.

\section{Declarations}

Ethical approval Not applicable.

\section{Consent to participate Not applicable.}

Consent to publish All authors whose names appear on the submission approved the version to be published and agree to be accountable for all aspects of the work in ensuring that questions related to the accuracy or integrity of any part of the work are appropriately investigated and resolved

Competing interests The authors declare no competing interests.

\section{References}

Andreoli V, Sprovieri F (2017) Genetic aspects of susceptibility to mercury toxicity: An overview. Int J of Environ Res Public Health 14(1):93
Barbosa JS, Cabral TM, Ferreira DN, Agnez-Lima LF, De Medeiros SB (2010) Genotoxicity assessment in aquatic environment impacted by the presence of heavy metals. Ecotoxicol Environ Saf 73(3): 320-325

Barrett B (2003) Medicinal properties of Echinacea: a critical review. Phytomedicine 10(1):66-86

Basu S, Datta AK, Pramanik A, Gupta S, Das D, Karmakar R, Ghosh B (2019) Assessment of cytotoxicity induced by heavy metal arsenic trioxide and azo-dye metanil yellow in Allium cepa assay and aqueous plant extracts mediated amelioration. Cytologia 84(3):263-269

Beauchamp C, Fridovich I (1971) Superoxide dismutase: improved assays and an assay applicable to acrylamide gels. Anal Biochem 44: 276-287

Beers RF, Sizer IW (1952) A spectrophotometric method for measuring the breakdown of hydrogen peroxide by catalase. J Biol Chem 195: 133-140

Bernhoft RA (2012) Mercury toxicity and treatment: a review of the literature. J Environ Public Health 2012:460508

Bolognesi C, Knasmueller S, Nersesyan A, Thomas P, Fenech M (2013) The HUMNxl scoring criteria for different cell types and nuclear anomalies in the buccal micronucleus cytome assay - an update and expanded photogallery. Mutat Res 753(2):100-113

Branco V, Caito S, Farina M, Teixeira da Rocha J, Aschner M, Carvalho C (2017) Biomarkers of mercury toxicity: past, present, and future trends. J Toxicol Environ Health B 20(3):119-154

Çavuşoğlu K, Acar A, Yalçın E (2018) Civa (Hg) ağır metal iyonunun Allium cepa L. (soğan)'da teșvik ettiği fizyolojik, sitogenetik ve anatomik değişimlerin araştırılması. DÜBITED 6(4):887-892

Chen YA, Chi WC, Huang TL, Lin CY, Nguyeh TTQ, Hsiung YC, Chia LC, Huang HJ (2012) Mercury-induced biochemical and proteomic changes in rice roots. Plant Physiol Biochem 55:23-32 
Cheng ZY, Sun X, Liu P, Lin B, Li LZ, Yao GD, Huang XX, Song SJ (2020) Sesquiterpenes from Echinacea purpurea and their antiinflammatory activities. Phytochemistry 179:112503

Cho UH, Park JO (2000) Mercury-induced oxidative stress in tomato seedlings. Plant Sci 156(1):1-9

Clarkson TW, Magos L (2006) The toxicology of mercury and its chemical compounds. Crit Rev Toxicol 36:609-662

Coelho J, Barros L, Dias MI, Finimundy TC, Amaral JS, Alves MJ, Calhelha RC, Santos PF, Ferreira ICFR (2020) Echinacea purpurea (L.) Moench: chemical characterization and bioactivity of its extracts and fractions. Pharmaceuticals 13(6):125

Crespo-López ME, Macêdo GL, Pereira SI, Arrifano GP, Picanço-Diniz DL, JLM DN, Herculano AM (2009) Mercury and human genotoxicity: critical considerations and possible molecular mechanisms. Pharmacol Res 60(4):212-220

Dalby-Brown L, Barsett H, Landbo AKR, Meyer AS, Mølgaard P (2005) Synergistic antioxidative effects of alkamides, caffeic acid derivatives, and polysaccharide fractions from Echinacea purpurea on in vitro oxidation of human low-density lipoproteins. J Agric Food Chem 53(24):9413-9423

Driggins SN, Whalen M, Myles EL (2017) The inhibitory effect of Echinacea purpurea and Echinacea pallida on BT-549 and natural killer cells. MOJ Cell Sci Rep 4(3):00091

Espinosa-Paredes DA, Cornejo-Garrido J, Moreno-Eutimio MA, Martínez-Rodríguez OP, Jaramillo-Flores ME, Ordaz-Pichardo C (2020) Echinacea angustifolia DC extract induces apoptosis and cell cycle arrest and synergizes with paclitaxel in the MDA-MB-231 and MCF-7 human breast cancer cell lines. Nutr Cancer:1-19

Fenech M, Chang WP, Kirsch-Volders M, Holland N, Bonassi S, Zeiger E (2003) HUMN project: detailed description of the scoring criteria for the cytokinesis-block micronucleus assay using isolated human lymphocyte cultures. Mutat Res Genet Toxicol Environ Mutagen 534(1-2):65-75

Glińska S, Bartczak M, Oleksiak S, Wolska A, Gabara B, Posmyk M, Janas K (2007) Effects of anthocyanin-rich extract from red cabbage leaves on meristematic cells of Allium cepa $\mathrm{L}$. roots treated with heavy metals. Ecotoxicol Environ Saf 68(3):343-350

Gupta K, Mishra K, Srivastava S, Kumar A (2018) Cytotoxic assessment of chromium and arsenic using chromosomal behavior of root meristem in Allium cepa L. Bull Environ Contam Toxicol 100(6):803808

Hansen JM, Choe HS, Carney EW, Harris C (2001) Differential antioxidant enzyme activities and glutathione content between rat and rabbit conceptuses. Free Radic Biol Med 30:1078-1088

Hohmann J, R Edei D, Forgo P, Szab OP, Freund TF, Haller J, Bojnik E, Benyhe S (2011) Alkamides and a neolignan from Echinacea purpurea roots and the interaction of alkamides with G-proteincoupled cannabinoid receptors. Phytochemistry 72:1848-1853

Hou R, Xu T, Li Q, Yang F, Wang C, Huang T, Hao Z (2020) Polysaccharide from Echinacea purpurea reduce the oxidant stress in vitro and in vivo. Int J Biol Macromol 149:41-50

Huang YL, Cheng SL, Lin TH (1996) Lipid peroxidation in rats administered with mercuric chloride. Biol Trace Elem Res 52:193-206

Islam MT, Quispe C, Mubarak MS, Salehi B, Reiner Ž, Martorell M, Sharifi-Rad J, Setzer WN (2021) Protective effects of natural products and their derivatives on genetic material: a critical review. Rec Nat Prod 15(6):433-462

Joksić G, Petrović S, Joksić I, Leskovac A (2009) Biological effects of Echinacea purpurea on human blood cells. Arh Hig Rada Toksikol 60(2):165-172

Kalefetoğlu Macar T, Macar O, Yalçın E, Çavuşoğlu K (2021) Protective roles of grape seed (Vitis vinifera $\mathrm{L}$.) extract against cobalt (II) nitrate stress in Allium cepa L. root tip cells. Environ Sci Pollut Res 28(1): 270-279

Karg CA, Wang P, Vollmar AM, Moser S (2019) Re-opening the stage for Echinacea research - Characterization of phylloxanthobilins as a novel anti-oxidative compound class in Echinacea purpurea. Phytomedicine 60:152969

Karimi N, Behbahani M, Dini G, Razmjou A (2019) Anticancer effects of Echinacea purpurea extracts, treated with green synthesized $\mathrm{ZnO}$ nanoparticles on human breast cancer (MCF-7) and PBMCs proliferation. Mater Res Express 6(9):095402

Koriem KMM (2020) Caftaric acid: An overview on its structure, daily consumption, bioavailability and pharmacological effects. Biointerface Res Appl Chem 10:5616-5623

Leme DM, Marin-Morales MA (2009) Allium cepa test in environmental monitoring: a review on its application. Mutat Res Rev Mutat Res 682(1):71-81

Macar O, Kalefetoğlu Macar T, Çavușoğlu K, Yalçın E (2020) Determination of protective effect of carob (Ceratonia siliqua L.) extract against cobalt (II) nitrate-induced toxicity. Environ Sci Pollut Res 27(32):40253-40261

Mohamed SM, Shalaby MA, Prince AM, Almokaddem AK, Elbanna HA (2020) Protective effect of Echinacea purpurea herb extracts against reproductive toxicity in male rats. Pharm Chem J 7(6):30-37

Nadaf M, Joharchi MR, Amiri MS (2019) Ethnomedicinal uses of plants for the treatment of nervous disorders at the herbal markets of Bojnord, North Khorasan Province, Iran. Avicenna J Phytomed 9: 153-163

Nagajyoti PC, Lee KD, Sreekanth TVM (2010) Heavy metals, occurrence and toxicity for plants: a review. Environ Chem Lett 8(3): 199-216

Patra M, Sharma A (2000) Mercury toxicity in plants. Bot Rev 66(3): $379-422$

Rodríguez-Sánchez R, Ortiz-Butrón R, Blas-Valdivia V, HernándezGarcía A, Cano-Europa E (2012) Phycobiliproteins or Cphycocyanin of Arthrospira (Spirulina) maxima protect against $\mathrm{HgCl}_{2}$-caused oxidative stress and renal damage. Food Chem 135(4):2359-2365

Sahu GK, Upadhyay S, Sahoo BB (2012) Mercury induced phytotoxicity and oxidative stress in wheat (Triticum aestivum L.) plants. Physiol Mol Biol Plants 18(1):21-31

Seth CS, Misra V, Chauhan LKS, Singh RR (2008) Genotoxicity of cadmium on root meristem cells of Allium cepa: cytogenetic and Comet assay approach. Ecotoxicol Environ Saf 71(3):711-716

Sharif KOM, Tufekci EF, Ustaoglu B, Altunoglu YC, Zengin G, LlorentMartínez EJ, Guney K, Baloglu MC (2021) Anticancer and biological properties of leaf and flower extracts of Echinacea purpurea (L.) Moench. Food Biosci 41:101005

Sharma PC, Gupta PK (1982) Karyotypes in some pulse crops. Nucleus 25:181-185

Sharma S, Nagpal A, Vig AP (2012) Genoprotective potential of Brassica juncea (L.) Czern. against mercury-induced genotoxicity in Allium cepa L. Turk J Biol 36(6):622-629

Signer J, Jonsdottir HR, Albrich WC, Strasser M, Züst R, Ryter S, Ackermann-Gäumann R, Lenz N, Siegrist D, Suter A, Schoop R, Engler OB (2020) In vitro virucidal activity of Echinaforce®, an Echinacea purpurea preparation, against coronaviruses, including common cold coronavirus 229E and SARS-CoV-2. Virol J 17(1): 136

Singh N, Sharma B (2020) Phytochemicals as therapeutics in heavy metal toxicity. In: Patra JK, Shukla AC, Das G (eds) Advances in pharmaceutical biotechnology. Springer, Singapore, pp 91-100

Sousa SG, Oliveira LA, de Aguiar MD, de Brito TV, Batista JA, Pereira CMC, de SouzaCosta M, Mazulo JCR, de Carvalho FM, Vasconselos DFP, da Silva DA, Barros FCN, Sombra VG, Freitas ALP, Monteiro RC, de Paula RCM, de Andrade Feitosa JP, dos Reis Barbosa AL (2018) Chemical structure and anti-inflammatory effect of polysaccharide extracted from Morinda citrifolia Linn (Noni). Carbohydr Polym 197:515-523

Spiller HA (2018) Rethinking mercury: the role of selenium in the pathophysiology of mercury toxicity. Clin Toxicol 56(5):313-326 
Teixeira FB, de Oliveira AC, Leão LK, Fagundes NC, Fernandes RM, Fernandes LMP, da Silva MCF, Amado LL, Sagica FES, de Oliveira EHC, Crespo-Lopez ME, Maia CSF, Lima RR (2018) Exposure to inorganic mercury causes oxidative stress, cell death, and functional deficits in the motor cortex. Front Mol Neurosci 11: 125

Tsai YL, Chiou SY, Chan KC, Sung JM, Lin SD (2012) Caffeic acid derivatives, total phenols, antioxidant and antimutagenic activities of Echinacea purpurea flower extracts. LWT 46(1):169-176

Tütüncü E, Yalçın E, Acar A, Yapar K, Çavusoglu K (2019) Investigation of the toxic effects of carbamate insecticide methiocarb in Allium cepa L. Cytologia 84:1-5

Unyayar S, Celik A, Cekic FO, Gozel A (2006) Cadmium-induced genotoxicity, cytotoxicity and lipid peroxidation in Allium sativum and Vicia faba. Mutagenesis 21:77-81

Xu W, Zhu H, Hu B, Cheng Y, Guo Y, Yao W, Qian H (2021) Echinacea in hepatopathy: A review of its phytochemistry, pharmacology, and safety. Phytomedicine $87: 153572$
Yıldız M, Ciğerci İH, Konuk M, Fidan AF, Terzi H (2009) Determination of genotoxic effects of copper sulphate and cobalt chloride in Allium cepa root cells by chromosome aberration and comet assays. Chemosphere 75(7):934-938

Ynalvez R, Gutierrez J, Gonzalez-Cantu H (2016) Mini-review: toxicity of mercury as a consequence of enzyme alteration. Biometals 29(5): 781-788

Zhang T, Lu Q, Su C, Yang Y, Hu D, Xu Q (2017) Mercury induced oxidative stress, DNA damage, and activation of antioxidative system and Hsp70 induction in duckweed (Lemna minor). Ecotoxicol Environ Saf 143:46-56

Publisher's note Springer Nature remains neutral with regard to jurisdictional claims in published maps and institutional affiliations. 